\title{
Research on the Matching of Organizational Change and Enterprise Transformation
}

\author{
Qinghong Meng*, Zhiwei HeLian, Baoyue Zhao \\ College of Economics and Management, Yanshan University, Qinhuangdao 066004, China \\ *Corresponding Author.
}

\begin{abstract}
Enterprise transformation is an important way for enterprises to gain sustainable competitive advantage. This paper aims to study the relationship between organizational change and enterprise transformation. Based on 303 valid questionnaires, the results show that organizational change has a positive impact on enterprise transformation. Organizational change has a positive effect on management innovation. Management innovation plays an intermediary role between organizational change and enterprise transformation. Employees' attitude toward change plays a regulating role between organizational change and enterprise transformation, while employees' attitude toward change plays a regulating role between organizational change and management innovation. Self-motivation plays a second-order role in the adjustment of employees' attitude towards organizational change and enterprise transformation. Self-motivation plays an insignificant role in adjusting organizational change and management innovation. Organizational motivation plays a second-order role in the adjustment of employees' attitude towards organizational change and enterprise transformation. Organizational motivation plays a second-order role in adjusting organizational change and management innovation.
\end{abstract}

Keywords: Organizational Change, Management Innovation, Enterprise Transformation, Employees' Attitudes toward Change, Motivation

\section{Introduction}

With the continuous development of economic globalization and the promotion of the information technology revolution, coupled with the increasingly complex and changeable domestic and foreign environment, the market competition has become extremely fierce. According to the relevant statistics of enterprises in recent years, the average life span of the group companies in China is 7 to 8 years, and the average life span of small and medium-sized enterprises is only 2.9 years whereas it is 7 to 8 years in the United States. The average life span of the large enterprises in the United States is about 40 years. There is a huge gap between U.S. and Chinese enterprises.

When an enterprise encounters an insurmountable survival gap, choosing transformation is one of the most important paths, which can provide the enterprise with new goals and development directions. The industrial transformation of enterprises can be roughly divided into two categories. One is the transformation to related industries, such as entering the upstream and downstream industries in the industrial chain to strengthen the sharing of resources and capabilities. The second category is abrupt transformation, that is, the enterprise transforms to an industry that has nothing to do with the existing business (also called cross-industry transformation), and the new industry field that it enters cannot share the resources and capabilities that have been formed. From the perspective of the requirements of enterprise transformation, whether it is a transformation to a related industry or a sudden transformation, it will put forward new requirements for the operation of the organization. Therefore, the study of general corporate transformation has universal theoretical and practical significance. The reason for studying the general transformation activities of enterprises is that all transformation enterprises have common characteristics: establishing new businesses, building new competitive advantages, and pursuing better performance. These characteristics belong to the category of strategic management and involve the

ISSN: 0010-8189

(C) CONVERTER 2020

www.converter-magazine.info 
question of the extent to which the existing organizational state supports the transformation, and the adjustment of the organizational state will directly affect the success rate of the transformation. It can be seen that enterprise transformation is an important strategic arrangement involving a full range of organizational activities. Among them, organizational change can provide impetus and guarantee for enterprise transformation. The reason is that having an efficient operation organization that matches the transformation requirements will greatly promote the successful transformation of the enterprise. The core content of corporate organizational reform is management innovation. In the process of matching organizational reform and corporate transformation, management innovation improves the operational efficiency of the organization and promotes corporate transformation through internal organization specifications, process re-engineering, management changes, and adjustments to employee tasks and functions. Therefore, the entire process of organizational change requires the active participation of employees [1]. However, the process of organizational change will break the original profit distribution pattern, the original operating mechanism needs to be re-adjusted, and interpersonal relationships will also be changed. Therefore, the various effects brought about by organizational changes will seriously affect employees' psychological responses, and in turn affect their attitudes and behaviors toward corporate transformation. As a result, it makes the process and effectiveness of the change uncertain [2].

Based on this, given the requirements of transformation, it is worth exploring whether there are factors that can contribute to employees' perceptions of corporate transformation, their attitudes toward organizational change, and what changes it will bring. Based on the theories of enterprise transformation, organizational change, management innovation, employees' attitude towards change and incentive mechanism, this paper determines various variables and their influencing factors, and establishes a logical relationship. This study uses a combination of questionnaire survey and empirical research to evaluate the matching relationship between organizational change and corporate change, to explore whether there is a mediating effect of management innovation on both, and whether employees' attitude toward change has a moderating effect, to further verify whether organizational incentives have a second-order moderating function for enriching corporate change theory, and to provide support and reference for guiding practice.

\section{Literature Review}

Scholars at home and abroad have conducted researches on corporate transformation from different perspectives, from which they can find theoretical perspectives that can be used for reference in the research of this subject. Wang Jifa defines the transformation of enterprises as the fact that the reduced competitiveness or bleak development prospects in their industries lead enterprises to actively or passively adopt industrial transfers, and improve their competitiveness in the industry through organizational changes, enabling enterprises to obtain new vitality [3] and clarifying the important role of organizational change in transformation. Lin et al point out that transformation can bring benefits to companies, such as expanding business operations and being compatible with the culture, values and needs of other companies and stakeholders to obtain market opportunities [4], emphasizing that the purpose of transformation is to obtain greater benefits and seize better market opportunities. Espejo proposes that corporate transformation requires the cooperation of the organization. Starting from the strategic alignment and change of the enterprise, the organization needs to combine itself with organizational structure and business process changes, which in turn drives the organization to meet the needs of corporate transformation [5], highlighting the requirement of adaptability in the transformation process, and organizational change must be closely related to business processes. Gill points out that corporate transformation is caused by changes in the economic environment and market environment. In order to narrow the gap between the actual value and the ideal value of the company, we need to make up for it through reform [6]. Mónica et al. believe that organizational change is a series of processes aimed at transforming organizational practices. These practices are carried out by employees, and they must adjust their behaviors to adapt to the realization of practices [7], and adapt the organization to the transformation required by the transformation as well as the participation of employees. Attitudes and behaviors are linked, and they deeply recognize the important role of employees in the 
transformation process. However, the content of organizational change involves strategy, organizational structure, business processes and corporate culture. The adjustment and change of corporate organizational structure will cause a series of management problems. The original management model and philosophy hinder the improvement and development of organizational efficiency. Therefore, Su Jingqin and other scholars believe that management innovation is based on the independent creation of internal and external environment or the introduction of existing management ideas or practices, processes, skills and structures, which are integrated, modified and implemented in order to achieve more effective use of resources and continuous improvement of the organization. The process of efficiency and performance [8] fully emphasizes the important role of management innovation in enterprise transformation and organizational change. Fu Qingfen and others point out that through management innovation in the fields of $R \& D$, production and sales, enterprises have laid an important foundation for the growth of enterprises, improved their management capabilities, and enabled enterprises to better participate in market competition [9], and pointed out management innovation plays a key role in the production and operation of enterprises. From this, it is believed that management innovation can also play a key role in the process of corporate transformation.

However, research shows that organizational change has a high failure rate [10]. The operation of an enterprise requires the participation of employees, and if major changes occur in business operations, employees will be the first to bear the brunt. Employees' behaviors towards change are affected by their perceptions of change and affect their attitudes, behaviors and future decisions. Fan Yun et al. find that when managers promote organizational change, they must fully consider the impact of employees' attitudes toward change [11]. Because employees will have a positive attitude to participate in the change when the organizational change can bring them opportunities and vital benefits; if employees feel that their current interests have been lost, they will hold a negative attitude towards the change, or even resist the change. Zhao Jing and others believe that enterprise managers adopt appropriate incentive strategies to effectively influence the organization members' attitudes towards change and the effect of change [12]. Scholars, from multiple perspectives, have found that employees' understandings of enterprise transformation and organizational change will influence their attitudes, behaviors, and degree of participation. At the same time, positive cognition can generate self-motivation, and organizational motivation can guide and change employees' behavior.

When incentives are introduced into the business process, it mainly refers to adopting various effective methods to mobilize employees' enthusiasm for work, so that they can work hard to complete the tasks assigned by superiors and achieve the goals of the organization. Chen Jingqiu and others point out that the attitude of employees towards change is an important factor influencing the success of organizational change [13]. Vanessa et al. confirm that if the quality of life and happiness of employees are planned in the process of implementing changes, negative attitudes can be minimized, thereby reducing the negative impact on employees' happiness. Therefore, when resistance is handled well, employees' behavior will promote the process of change [14]. Zeng Xiangquan and others find that the basic salary increase mechanism and the construction of corporate incentive mechanism have a positive and significant impact on the behavior change of employees [15]. Scholars not only confirm that incentives have an impact on employees' behaviors, but also further discover the factors that contribute to incentives, which provides in-depth inspiration for the study of this article. It is a question whether the establishment of a sound incentive strategy will promote the transformation of employees' attitudes towards transformation, and then promote the process of organizational transformation, and realize the successful transformation of the enterprise. For this reason, this article divides motivation into two dimensions, self-motivation and organizational motivation, and explores the degree of influence of the two dimensions on employees' attitudes towards change.

From the literature research at home and abroad, it can be seen that the research on the content of enterprise transformation and organizational change focuses on their direct relationship. The indirect influence factors between them, the relationship between these indirect factors, the relationship between them and the transformation of the enterprise and organizational change have not been studied. If we do not explore the 
relationship between these indirect factors in transformation and organizational change, it will be incomplete from the perspective of improving the theory of enterprise transformation or guiding the practice of enterprise transformation. Therefore, based on the objectives and requirements of this article and literature review, this paper summarizes and refines the research results of predecessors, and preliminarily determines the six variables which are organizational transformation, organizational change, management innovation, employee transformation attitude, self-motivation and organizational motivation. Through questionnaire survey and data analysis, this paper studies the matching between organizational change and enterprise transformation, further improves the theory of enterprise transformation, and provides some guidance for the practice of enterprise transformation.

\section{Theoretical Analysis and Research Hypothesis}

\subsection{Organizational Change and Enterprise Transformation}

With the development of science and technology and the increasingly fierce competition in the market environment, it is increasingly difficult for companies to maintain their dominant position in the market for a long time. In the face of competitive pressure and development opportunities, the choice of transformation may be a way for enterprises to seek new development. From the transformation practice of some enterprises, new growth points and new competitive advantages can be obtained through transformation. Enterprise transformation requires organizational change to provide motivation and guarantee. Organizational transformation is to form a driving force to support and promote enterprise transformation through the adjustment and change of enterprise strategy, organizational structure, business process and corporate culture, and to complete the transformation task. Scholars affirm that corporate strategic change has an important impact on the future development of enterprises [16]. Enterprise transformation is one of the contents of corporate strategic management, and strategic management must inevitably require organizational adjustment and consistency with the transformational strategic objectives. Bhatt and others believe that the optimization and reorganization of organizational structure provide important guarantees for corporate resources in the process of accelerating corporate transformation [17]. It can be seen that the organizational structure which is compatible with the transformation goals can show positive organizational advantages and improve the efficiency of transformation. On the contrary, the unsuitable and rigid organizational structure will hinder and limit the vitality of the organization, and it is difficult to play the organizational function to effectively promote the successful transformation of the enterprise. Therefore, organizational change will play an important role in organizational performance and corporate transformation [18]. Accordingly, the following hypotheses are proposed:

H1: Organizational change has a positive effect on corporate transformation.

\subsection{The mediating role of management innovation}

In the real competitive environment, one way to gain competitive advantage for enterprises is to rely on technological innovation. Management innovation is gradually becoming an important guarantee for enterprises to obtain sustainable competitive advantages [19]. The results of organizational changes will involve many issues such as changes in work, power and status, changes in salaries and benefits, and changes in interpersonal relationships [20]. If these problems are not resolved in a timely and good manner, it will exacerbate new problems such as departmental communication barriers, insufficient work motivation of employees, and low organizational efficiency [21]. Therefore, it is necessary to use management innovation to reform the work process, adjust the tasks and functions of employees, improve management methods, promote the update and introduction of new management concepts and management systems, and strengthen departmental communication to improve organizational efficiency and corporate core competitiveness [22], which in turn promotes corporate transformation. The research of D'Amato and Roome shows that management innovation will indeed promote the improvement of corporate efficiency, thereby enhancing the company's competitive advantage [23]. Its fundamental role is that management innovation has an overall effect on its local improvements of management concepts, systems, 
processes, and organizational structures which will form overall management advantages, and accelerate the transformation of the enterprise and promote the sustainable development of the enterprise. Therefore, the following assumptions are made:

$\mathrm{H} 2 \mathrm{a}$ : Organizational change has a positive impact on innovation management.

$\mathrm{H} 2 \mathrm{~b}$ : Management innovation has a positive impact on corporate transformation.

$\mathrm{H} 2 \mathrm{c}$ : Management innovation plays an intermediary role in organizational change and enterprise transformation.

\subsection{The moderating effect of employees' attitudes towards change}

Due to changes in the internal and external environment, companies need to adjust their development strategies in a timely and effective manner to adapt to the requirements of the new environment. The adjustment strategy of the enterprise leads to the adjustment of the organizational structure. However, organizational changes are not always successful. Nearly three-quarters of enterprises will have serious problems, resulting in a decline in their production capacity and efficiency or loss of personnel [24]. The key to the success of organizational change is not the defect of the change itself, but the attitude and response of employees to the change in the process of change [25]. Organizational changes such as organizational structure adjustments and changes have laid an important foundation for the introduction of new management methods, management systems and management concepts. However, as the "basic element" of the organization's operation, employees are widely involved in the production and operation activities of the enterprise. If the organizational change causes the employees' daily behavioral inertia to be broken, they will be afraid that the organizational change will bring losses to their current self-interests, and lack the sense of security to the change, unprecedented worries and anxiety in the face of new challenges, which will gradually distrust the organization, and then generate dissatisfaction, and even adopt a negative attitude to hinder the transformation of the enterprise. Of course, there will also be employees who have brought unprecedented changes to the company due to the introduction of new management concepts and management methods, seeing the bright prospects and expectations of the development of individuals and the company, they will be more actively involved in the reform and regard participating in the reform as opportunities for progress, learning and growth [26]. It explains that employees' personal perceptions of enterprise transformation and organizational change will show different responses and behaviors to organizational change, and affect the transformation process and results of the enterprise. Based on this, hypotheses are put forward:

H3a: Employee's attitude to change regulates the relationship between organizational change and management innovation.

H3b: Employee's attitude to change regulates the relationship between organizational change and enterprise transformation.

\subsection{The second-order adjustment effect of self-motivation and organizational motivation}

The incentive strategy plays an important guiding role in corporate transformation, which involves changes in all aspects of the organization, and the future is full of uncertainties and unknowns. Therefore, enterprise transformation requires the active participation and creativity of employees to overcome the complexity of transformation. He Wei et al. point out that long-term and stable incentives for employees can meet the complex psychological needs of employees and have an important impact on the change of their behaviors [27]. Therefore, it is necessary to adjust the behaviors and goals of employees through incentives to ensure the smooth transformation of the enterprise [28]. Self-motivation mainly emphasizes that employees are to realize their self-worth. When an individual perceives that work is meaningful and important to oneself, he will devote more time and energy to do it well [29]. Organizational incentives mainly emphasize that employees value tangible rewards such as material rewards, benefits, and career advancement. Studies have proved that the organizational incentive has an important impact on employee behaviors [30]. Employees' positive evaluation of the incentives given by the organization during the change will not only improve their behaviors to support the change, but also generate a positive premonition for the change. This positive expectation will prompt the employees to have more 
positive behaviors and form a positive effect on the attitude towards change [31]. Therefore, during the transformation of the company, once the inertia of employees' thinking and behavior is broken, it will inevitably affect their attitudes. If an enterprise adopts a positive incentive policy, changes the attitude and behavior of employees, and guides them to actively participate in management innovation activities, it will definitely benefit the transformation of the enterprise. Therefore, the hypotheses are put forward:

H4a: Self-motivation plays a significantly second-order and moderating role in the moderating role of employees' change attitudes on organizational change and management innovation.

H4b: Self-motivation plays a significantly second-order and moderating role in the moderating role of employees' change attitudes on organizational change and corporate transformation.

H4c: Organizational incentive plays a significantly second-order and regulatory role in the moderating role of employee change attitudes on organizational change and management innovation.

$\mathrm{H} 4 \mathrm{~d}$ : Organizational incentive plays a significantly second-order and regulatory role in the moderating role of employee change attitudes on organizational change and corporate transformation.

Enterprise transformation is a major strategic decision in the process of its business development. Therefore, the transformation of an enterprise will inevitably require organizational structure as a guarantee for its transformation. According to the theory of enterprise transformation and organization theory, enterprise transformation (dependent variable) will inevitably require organizational transformation (independent variable) to match it well. In this matching process, it will inevitably involve the influence of corporate management innovation on the matching relationship between organizational change and transformation, so as to promote the formation of new functions of organizational reform to ensure the needs of transformation and promote the success of corporate transformation. Based on this, it is necessary to verify whether the management innovation of the transformation enterprise has an intermediary effect on enterprise transformation and organizational transformation. At the same time, according to demand theory, motivation theory, and behavior theory, the participation of employees is required in the process of corporate transformation and organizational change, and the participation of employees is also required in the process of playing a role in management innovation capabilities. The attitude of employees' participation will affect their behaviors and which will directly affect the matching process of organizational change and transformation, and also affect the role of management innovation ability in the process of organizational change. Therefore, employees' attitudes may have the moderating role in these two aspects. In addition, the attitudes of employees are affected by externally and internally motivational factors. It can be seen that motivating factors also have some moderating effects on employees' attitudes towards participation. This shows that in the process of corporate transformation, it is necessary not only to study the matching problem of organizational change and transformation, but also to study the possible intermediary variables and moderating variables in the matching relationship, and to study whether there are still related influencing factors in the deep level. From this, it reveals the influencing relationships of complex factors, and provides theoretical guidance for scientifically and systematically solving enterprise transformation problems. For this reason, the research task of this article is to verify whether these interactions exist.

Constructing a theoretical model based on the relationship between the variables and influencing factors formed by the above assumptions, it is shown in Figure 1.

ISSN: 0010-8189 


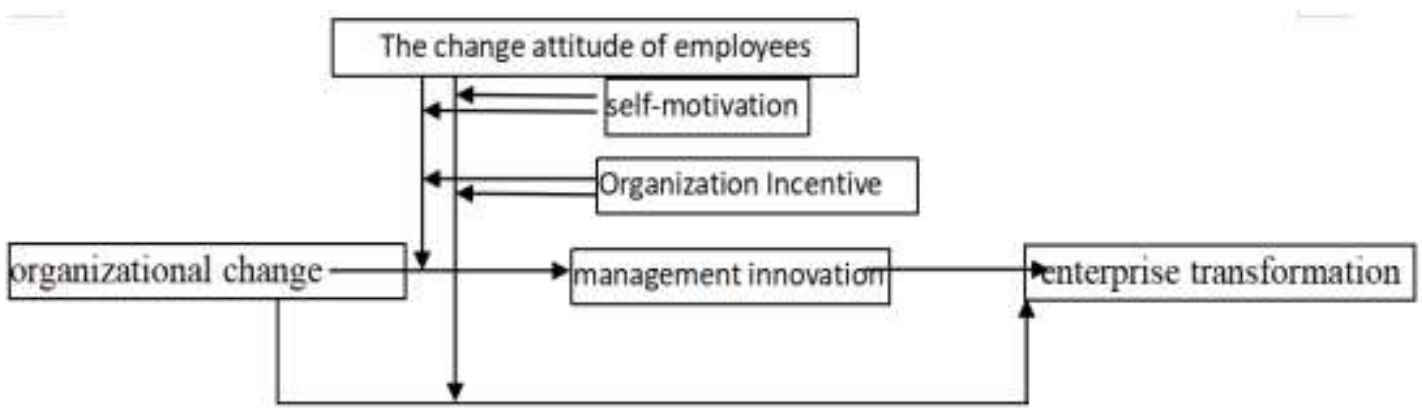

Figure 1 Theory Model

Fig 1: Theory Model

\section{Research Design}

\subsection{Sample and data collection}

The questionnaire survey method is widely used in social surveys to study practical problems or phenomena. It is a method by which researchers use questionnaires to control measurements and measure research questions to collect reliable information. Due to the certain degree of professionalism and complexity in the transformation of enterprises, the targeted survey subjects should undertake certain tasks of the transformation, and be able to make objective judgments on the specific conditions of their enterprises. This study uses anonymous method to fill out the questionnaire, and assured the interviewees that the content of the questionnaire would not involve personal privacy or confidential corporate information. The investigation process uses a combination of online and offline forms, and the information collected is only for academic research. A total of 350 questionnaires were distributed in this survey, and 329 were actually received. Invalid and incomplete questionnaires were excluded. Finally, 303 valid questionnaires were obtained. The basic information and statistical results of the sample are shown in Table 1 .

Table 1 Basic information of the sample

\begin{tabular}{|c|c|c|c|}
\hline \multicolumn{2}{|l|}{ Samples } & Number & Proportion (\%) \\
\hline \multirow{3}{*}{ Gender } & Male & 137 & 45.2 \\
\cline { 2 - 4 } & Female & 166 & 54.8 \\
\hline \multirow{4}{*}{ Age } & 25 and below & 80 & 26.4 \\
\cline { 2 - 4 } & $26-35$ & 159 & 52.5 \\
\cline { 2 - 4 } & $36-45$ & 39 & 12.9 \\
\cline { 2 - 4 } & $46-55$ & 25 & 8.3 \\
\cline { 2 - 4 } & Education background above & 0.0 & 0.0 \\
\hline & High school and below & 25 & 8.3 \\
\cline { 2 - 4 } & Junior college & 90 & 29.7 \\
\cline { 2 - 4 } & Bachelor & 188 & 62 \\
\cline { 2 - 4 } & Master's degree & 0.0 & 0.0 \\
\cline { 2 - 4 } & PhD & 0.0 & 56.8 \\
\hline \multirow{5}{*}{ Job position } & Ordinary employees & 172 & 30.7 \\
\cline { 2 - 4 } & Grassroots managers & 93 & 0.0 \\
\cline { 2 - 4 } & Middle managers & 38 & 0.0 \\
\cline { 2 - 4 } & Senior managers & 0.0 & 0.0 \\
\cline { 2 - 4 } & Professional technical & 0.0 & \\
\hline
\end{tabular}

ISSN: 0010-8189

(C) CONVERTER 2020 


\begin{tabular}{|c|c|c|c|}
\hline \multirow{5}{*}{ Working experience } & Less than 2 years & 56 & 18.5 \\
\hline & 2-5 years (including 5 years) & 111 & 36.5 \\
\hline & 5-8 years (including 8 years) & 45 & 14.9 \\
\hline & $\begin{array}{c}\text { 8-11 years (including } 11 \\
\text { years) }\end{array}$ & 27 & 8.9 \\
\hline & 11 years and above & 64 & 21.1 \\
\hline \multirow{5}{*}{ Enterprise scale } & 100 employees and below & 61 & 20.1 \\
\hline & $101-500$ & 53 & 17.5 \\
\hline & $501-2000$ & 105 & 34.7 \\
\hline & $2001-5000$ & 68 & 22.4 \\
\hline & More than 5000 & 16 & 5.3 \\
\hline \multirow{5}{*}{ Enterprise age } & Under 3 years & 0.0 & 0.0 \\
\hline & 3-7 years (including 7 years) & 9.0 & 3.0 \\
\hline & $\begin{array}{c}\text { 7-10 years (including } 10 \\
\text { years) }\end{array}$ & 62 & 20.5 \\
\hline & $\begin{array}{c}\text { 10-15 years (including } 15 \\
\text { years) }\end{array}$ & 122 & 40.3 \\
\hline & More than 15 years & 110 & 36.3 \\
\hline \multirow{5}{*}{$\begin{array}{c}\text { The average total profit } \\
\text { of the enterprise in the } \\
\text { past three years }\end{array}$} & Loss & 61 & 20.1 \\
\hline & $\begin{array}{l}0-5 \text { million (including } 5 \\
\text { million) }\end{array}$ & 107 & 35.3 \\
\hline & $\begin{array}{l}\text { 5-10 million yuan (including } \\
10 \text { million yuan) }\end{array}$ & 23 & 7.6 \\
\hline & $\begin{array}{l}10 \text { million-50 million } \\
\text { (including } 50 \text { million) }\end{array}$ & 80 & 26.4 \\
\hline & Over 50 million yuan & 32 & 10.6 \\
\hline \multirow{5}{*}{$\begin{array}{l}\text { The average total sales } \\
\text { of enterprises in the } \\
\text { past three years }\end{array}$} & $\begin{array}{l}0-5 \text { million (including } 5 \\
\text { million) }\end{array}$ & 38 & 12.5 \\
\hline & $\begin{array}{l}\text { 5-50 million yuan (including } \\
50 \text { million yuan) }\end{array}$ & 123 & 40.6 \\
\hline & $\begin{array}{c}50-100 \text { million yuan } \\
\text { (including } 100 \text { million yuan)) }\end{array}$ & 111 & 36.6 \\
\hline & $\begin{array}{c}100-500 \text { million yuan } \\
\text { (including } 500 \text { million yuan) })\end{array}$ & 27 & 8.9 \\
\hline & Over 500 million yuan & 4.0 & 1.3 \\
\hline
\end{tabular}

4.2 Variable measurement

The observation scale used in this research is derived from mature scales at home and abroad. Taking into account the local humanistic situation, the scale items have been adjusted and revised. Except for the control variables of the basic situation of individuals and enterprises, all other variables are observed using the Likert 5-point scale method. 1-5 means "strongly disagree, disagree, agree, quite agree, and strongly agree".

\subsubsection{Organizational change.}

Using the scale compiled by scholars such as Monica [7], the items were combined in the observation table of Huo Ming [32]. After 3 tests and corrections, 12 items were retained. The Cronbach's $\alpha$ value of this variable is 0.914 , indicating that it has good reliability.

\subsubsection{Management innovation.}

Using the scale developed by scholars such as Vaccaro [33], it includes 6 items such as "the company will regularly adjust the rules and procedures of doing things" and "the company will regularly adopt a new management system". The Cronbach's $\alpha$ value of this variable is 0.933 , indicating that it has good reliability. 
4.2.3 Enterprise transformation.

Combining the scale compiled and developed by Humphrey [34] and Kong Weijie [35], a scale suitable for this study was developed. After 3 measurements and corrections, 7 measurement items are finally retained. The Cronbach's $\alpha$ value of this variable is 0.950 , indicating that it has good reliability.

4.2.4 Employees' attitudes toward change.

The measurement scale of Lau and woodman [36] is used. After 3 tests, adjustments and corrections, a total of 6 items are retained. The Cronbach's $\alpha$ value of this variable is 0.921 , indicating that it has good reliability.

\subsubsection{Self-motivation.}

Using the scale studied by Yang Wuzhou [37], 3 items were retained after screening. The Cronbach's $\alpha$ value of this variable is 0.848 , indicating that it has good reliability.

4.2.6 Organizational incentives.

Using the scale developed by scholars such as Zhao Yiling and Duan Wanchun [38], the contents of the scale were selected and revised, and finally 3 items were retained. The Cronbach's $\alpha$ value of this variable is 0.837 , indicating that it has good reliability.

\subsubsection{Control variables.}

According to the research objectives of this article and the characteristics of each variable, the control variables are selected as: gender, age, education, working years, enterprise scale, enterprise age, average total profit and average total sales of the enterprise in the past three years.

\section{Data Analysis}

\subsection{Common method bias and validity test}

The method of Harman's single factor is used to test the homology of the questionnaire; it imports all the items of the questionnaire into SPSS25.0 for analysis and extracts the factors whose characteristic root is greater than 1 . If the data is not rotated, the variation of the first factor is explained. The amount is $22.906 \%$, and the total amount of variation explained is $77.127 \%$, which does not account for half of the total amount of variation explained. It shows that the homology error is not significant and will not affect the data analysis and research results. At the same time, AMOS24.0 software is used to perform confirmatory factor analysis on the measurement tools involved in this research to test the fit of the model. The model fitting indexes all reach the standard: $\mathrm{X} 2 / \mathrm{df}=1.061$, RMSEA $=0.014$, GFI=0.902, NFI=0.922, RFI=0.915, SRMR=0.038. The fitting effect of each index is good, and the model has a high degree of adaptation.

\subsection{Correlation analysis of major variables}

The correlation coefficients of the main variables are shown in Table 2. From the perspective of correlation coefficients, there is a significantly positive correlation between organizational change and employee change attitude $(r=0.283, p<0.001)$, organizational change and management innovation $(r=0.174, p<0.01)$, organizational change and corporate transformation $(\mathrm{r}=0.197, \mathrm{p}<0.01)$, enterprise transformation and management innovation $(\mathrm{r}=0.151, \mathrm{p}<0.01)$, self-motivation and employee change attitude $(\mathrm{r}=0.232, \mathrm{p}<0.001)$, organizational motivation and employee change attitude $(r=0.307, \mathrm{p}<0.001)$, organizational motivation and self-motivation $(\mathrm{r}=0.291, \mathrm{p}<$ $0.001)$.

Table 2 The mean, standard deviation and correlation coefficient of each main variable 
Volume 2021, No. 2

\begin{tabular}{|c|c|c|c|c|c|c|c|c|}
\hline Variable & $\begin{array}{l}\text { Mea } \\
\text { n } \\
\text { valu } \\
\mathrm{e}\end{array}$ & $\begin{array}{l}\text { Standar } \\
\text { d } \\
\text { Deviati } \\
\text { on }\end{array}$ & $\begin{array}{l}\text { Organizatio } \\
\text { nal Change }\end{array}$ & $\begin{array}{l}\text { Employ } \\
\text { ee } \\
\text { attitude } \\
\text { towards } \\
\text { change }\end{array}$ & $\begin{array}{c}\text { Self-motivat } \\
\text { ion }\end{array}$ & $\begin{array}{c}\text { Organizatio } \\
\text { nal } \\
\text { Incentive }\end{array}$ & $\begin{array}{c}\text { Managem } \\
\text { ent } \\
\text { Innovatio } \\
n\end{array}$ & $\begin{array}{c}\text { Enterprise } \\
\text { Transformat } \\
\text { ion }\end{array}$ \\
\hline $\begin{array}{l}\text { Organizatio } \\
\text { nal Change }\end{array}$ & $\begin{array}{c}3.31 \\
2 \\
\end{array}$ & 0.721 & 1 & & & & & \\
\hline $\begin{array}{c}\text { Employee } \\
\text { attitude } \\
\text { towards } \\
\text { change }\end{array}$ & $\begin{array}{c}3.02 \\
3\end{array}$ & 0.941 & $0.283^{* * *}$ & 1 & & & & \\
\hline $\begin{array}{l}\text { Self-motivat } \\
\text { ion }\end{array}$ & $\begin{array}{c}3.40 \\
4\end{array}$ & 0.932 & $0.133^{*}$ & $0.232^{* * * *}$ & 1 & & & \\
\hline $\begin{array}{c}\text { Organizatio } \\
\text { nal } \\
\text { Incentive }\end{array}$ & $\begin{array}{c}3.44 \\
0\end{array}$ & 0.851 & 0.062 & $0.307^{* * * *}$ & $0.291^{* * * *}$ & 1 & & \\
\hline $\begin{array}{l}\text { Managemen } \\
\mathrm{t} \text { Innovation }\end{array}$ & $\begin{array}{c}3.25 \\
3 \\
\end{array}$ & 0.870 & $0.174^{* *}$ & 0.069 & 0.001 & 0.100 & 1 & \\
\hline $\begin{array}{c}\text { Enterprise } \\
\text { Transformat } \\
\text { ion }\end{array}$ & $\begin{array}{c}3.28 \\
5\end{array}$ & 0.866 & $0.197^{* *}$ & 0.046 & $0.151^{* *}$ & 0.046 & $0.277^{* * *}$ & 1 \\
\hline
\end{tabular}

Note: $*$ means $\mathrm{p}<0.05, * *$ means $\mathrm{p}<0.01, * * *$ means $\mathrm{p}<0.001$. The same below.

\subsection{Hypothesis testing}

(1) This is the main effect test. SPSS25.0 is used to conduct hypothesis testing, and the direct effects of organizational change on management innovation and enterprise transformation are shown in Table 3. Management innovation is taken as the dependent variable, and model M2 shows that organizational change is positively correlated with management innovation $(\beta=0.161, \mathrm{p}<0.01)$, assuming H2a holds. In order to test the impact of organizational change and management innovation on enterprise transformation, the enterprise transformation is set as the dependent variable. Model M4 shows that organizational transformation and enterprise transformation are positively correlated $(\beta=0.158, \mathrm{p}<0.01)$, and the hypothesis $\mathrm{H} 1$ is verified.

Table 3 Test results of main effects and intermediate effects

\begin{tabular}{|c|c|c|c|c|c|c|}
\hline \multirow{2}{*}{ Variable } & \multicolumn{2}{|c|}{$\begin{array}{c}\text { Management } \\
\text { innovation }\end{array}$} & \multicolumn{4}{c|}{ Enterprise transformation } \\
\cline { 2 - 7 } & M1 & M2 & M3 & M4 & M6 \\
\hline $\begin{array}{c}\text { Gender } \\
\text { Age }\end{array}$ & $\begin{array}{c}-0.019 \\
0.138\end{array}$ & $\begin{array}{c}-0.019 \\
0.109\end{array}$ & $\begin{array}{c}-0.045 \\
0.085\end{array}$ & $\begin{array}{c}-0.045 \\
0.057\end{array}$ & $\begin{array}{c}-0.04 \\
0.05\end{array}$ & $\begin{array}{c}-0.041 \\
0.031\end{array}$ \\
\hline $\begin{array}{c}\text { Education } \\
\text { background }\end{array}$ & 0.035 & 0.043 & 0.142 & 0.149 & 0.133 & 0.139 \\
\hline Job position & 0.072 & 0.054 & 0.072 & 0.055 & 0.054 & 0.042 \\
\hline $\begin{array}{c}\text { Working } \\
\text { experience }\end{array}$ & -0.124 & -0.104 & -0.122 & -0.102 & -0.09 & -0.078 \\
\hline $\begin{array}{c}\text { Enterprise } \\
\text { scale }\end{array}$ & 0.006 & -0.012 & -0.046 & -0.064 & -0.048 & -0.061 \\
\hline Enterprise age & -0.109 & -0.1 & -0.018 & -0.009 & 0.01 & 0.014 \\
\hline Total profit & 0.095 & 0.124 & -0.003 & 0.025 & -0.027 & -0.004 \\
\hline Total sales & 0.019 & -0.029 & 0.147 & 0.1 & 0.142 & 0.107 \\
\hline Organizational & & $0.161^{* *}$ & & $0.158^{* *}$ & & $0.12^{*}$ \\
\hline
\end{tabular}

ISSN: 0010-8189 


\begin{tabular}{|c|c|c|c|c|c|c|}
\hline change & & & & & & \\
\hline $\begin{array}{c}\text { Management } \\
\text { innovation }\end{array}$ & & & & & $0.254^{* * *}$ & $0.236^{* * *}$ \\
\hline $\mathrm{R}^{2}$ & 0.028 & 0.051 & 0.6 & 0.083 & 0.123 & 0.136 \\
\hline$\triangle \mathrm{R}^{2}$ & -0.002 & 0.19 & 0.031 & 0.052 & 0.093 & 0.103 \\
\hline $\mathrm{F}$ & 0.929 & 1.576 & $2.09^{*}$ & $2.646^{* *}$ & $4.091^{* * *}$ & $4.155^{* * *}$ \\
\hline
\end{tabular}

(2) This is the mediation effect test of management innovation. In the aforementioned main effect test, it is verified that organizational change is positively correlated with management innovation and organizational change is positively correlated with enterprise transformation. Here model M5 shows that management innovation is positively correlated with enterprise transformation $(\beta=0.254, \mathrm{p}<0.001)$, assuming that $\mathrm{H} 2 \mathrm{~b}$ holds. It shows that the research results meet the test conditions of the mediation effect. To further verify the mediating effect of management innovation, model M6 is constructed. The results show that both organizational change and management innovation have a positive impact on business transformation $(\beta=0.12, p<0.05 ; \beta=0.236, p<0.001)$, and compared with model M4, organizational change has a positive impact on the return of business transformation. The coefficient drops from 0.158 to 0.12 , indicating that management innovation plays a part of the intermediary role between organizational change and enterprise transformation. Hypothesis $\mathrm{H} 2 \mathrm{c}$ holds.

(3) This is the test of the moderating effect of employees' attitudes towards change. In order to verify the moderating effect of employees' attitudes towards change, the model was sequentially added with control variables, organizational changes, employees' attitudes to change, and the interaction terms between organizational changes and employees' attitudes to change. The two were standardized before the product of organizational change and employee attitudes to change in order to avoid the influence of multi-collinearity. The results are shown in Table 4. The interaction item of organizational change and employee's attitude to change has a significant impact on management innovation $(\beta=0.214, \mathrm{p}<0.001)$. If $\mathrm{H} 3 \mathrm{a}$ is established, it shows that employee's attitude to change regulates the relationship between organizational change and management innovation.

Table 4 Test results of adjustment effect

\begin{tabular}{|c|c|c|c|c|}
\hline \multirow{2}{*}{ Variable } & \multicolumn{4}{|c|}{ Management innovation } \\
\hline & M7 & M8 & M9 & M10 \\
\hline Gender & -0.019 & -0.019 & -0.02 & -0.03 \\
\hline Age & 0.138 & 0.109 & 0.11 & 0.126 \\
\hline $\begin{array}{c}\text { Education } \\
\text { background }\end{array}$ & 0.035 & 0.043 & 0.043 & 0.045 \\
\hline Job position & 0.072 & 0.054 & 0.054 & 0.032 \\
\hline $\begin{array}{l}\text { Working } \\
\text { experience }\end{array}$ & -0.124 & -0.104 & -0.104 & -0.13 \\
\hline Enterprise scale & 0.006 & -0.012 & -0.017 & -0.023 \\
\hline Enterprise age & -0.109 & -0.1 & -0.099 & -0.079 \\
\hline Total profit & 0.095 & 0.124 & 0.126 & 0.102 \\
\hline Total sales & 0.019 & -0.029 & -0.028 & -0.019 \\
\hline $\begin{array}{l}\text { Organizational } \\
\text { change }\end{array}$ & & $0.161^{* *}$ & $0.154^{*}$ & $0.161^{* * *}$ \\
\hline $\begin{array}{c}\text { Employees' } \\
\text { Attitudes Toward } \\
\text { Change }\end{array}$ & & & 0.025 & 0.028 \\
\hline $\begin{array}{c}\text { Organizational } \\
\text { change } \times \text { attitude } \\
\text { of employees to } \\
\text { change }\end{array}$ & & & & $0.214^{* * *}$ \\
\hline $\mathrm{R}^{2}$ & 0.028 & 0.051 & 0.052 & 0.096 \\
\hline$\triangle \mathrm{R}^{2}$ & -0.002 & 0.019 & 0.016 & 0.059 \\
\hline
\end{tabular}

ISSN: 0010-8189 


\begin{tabular}{|l|l|l|l|l|}
\hline $\mathrm{F}$ & 0.929 & 1.576 & 1.444 & 2.565 \\
\hline
\end{tabular}

The above steps are repeated with the transformation of the enterprise as the dependent variable. The results are shown in Table 5. The interaction item of organizational change and employee change attitude has a significant impact on enterprise transformation $(\beta=0.172, p<0.01)$. If $\mathrm{H} 3 \mathrm{~b}$ is established, it shows that employee change attitude regulates the relationship between organizational change and enterprise transformation.

Table 5 Test results of adjustment effect

\begin{tabular}{|c|c|c|c|c|}
\hline \multirow{2}{*}{ Variable } & \multicolumn{4}{|c|}{ Enterprise transformation } \\
\hline & M11 & M12 & M13 & M14 \\
\hline Gender & -0.045 & -0.045 & -0.045 & -0.053 \\
\hline Age & 0.085 & 0.057 & 0.057 & 0.07 \\
\hline $\begin{array}{c}\text { Education } \\
\text { background }\end{array}$ & 0.142 & 0.149 & 0.149 & 0.151 \\
\hline Job position & 0.072 & 0.055 & 0.055 & 0.037 \\
\hline $\begin{array}{c}\text { Working } \\
\text { experience }\end{array}$ & -0.122 & -0.102 & -0.102 & -0.123 \\
\hline Enterprise scale & -0.046 & -0.064 & -0.064 & -0.069 \\
\hline Enterprise age & -0.018 & -0.009 & -0.009 & 0.007 \\
\hline Total profit & -0.003 & 0.025 & 0.025 & 0.007 \\
\hline Total sales & 0.147 & 0.1 & 0.1 & 0.107 \\
\hline $\begin{array}{l}\text { Organizational } \\
\text { change }\end{array}$ & & $0.158^{* *}$ & $0.158^{*}$ & $0.164^{* *}$ \\
\hline $\begin{array}{c}\text { Employees' } \\
\text { Attitudes Toward } \\
\text { Change }\end{array}$ & & & 0.0002 & 0.003 \\
\hline $\begin{array}{c}\text { Organizational } \\
\text { change } \times \text { attitude } \\
\text { of employees to } \\
\text { change }\end{array}$ & & & & $0.172^{* *}$ \\
\hline $\mathrm{R}^{2}$ & 0.06 & 0.083 & 0.083 & 0.112 \\
\hline$\triangle \mathrm{R}^{2}$ & 0.031 & 0.048 & 0.048 & 0.075 \\
\hline $\mathrm{F}$ & $2.090^{* *}$ & $2.397^{* *}$ & $2.397^{* *}$ & $3.042^{* *}$ \\
\hline
\end{tabular}

(4) This is the second-order moderating effect test of incentive variables. In order to further verify the second-order moderating effect of self-motivation and organizational motivation on management innovation, the model sequentially adds control variables, organizational change, employee change attitude, self-motivation, and interactive items of organizational change, employee change attitude and self-motivation. Before constructing interactive items, self-motivation is standardized. The results are shown in Table 6. The interaction items of organizational change, employee change attitude and self-motivation have no significant impact on management innovation, and the $\mathrm{H} 4 \mathrm{a}$ hypothesis does not hold. The above steps are repeated to standardize organizational incentives before interactive items. The results are shown in Table 6. The interaction items of organizational change, employee change attitudes and organizational incentives have significant impacts on management innovation $(\beta=0.169, \mathrm{p}<0.05)$, assuming $\mathrm{H} 4 \mathrm{c}$ holds.

Table 6 Test results of second-order adjustment effect

\begin{tabular}{|c|c|c|c|c|c|c|c|}
\hline \multirow{2}{*}{ Variable } & \multicolumn{7}{|c|}{ Management Innovation } \\
\cline { 2 - 8 } & M15 & M16 & M17 & M18 & M19 & M20 & M21 \\
\hline Gender & -0.019 & -0.019 & -0.02 & -0.02 & -0.02 & -0.019 & -0.015 \\
\hline Age & 0.138 & 0.109 & 0.11 & 0.106 & 0.098 & 0.109 & 0.075 \\
\hline Education & 0.035 & 0.043 & 0.043 & 0.044 & 0.045 & 0.037 & 0.03 \\
\hline
\end{tabular}


Volume 2021, No. 2

\begin{tabular}{|c|c|c|c|c|c|c|c|}
\hline background & & & & & & & \\
\hline Job position & 0.072 & 0.054 & 0.054 & 0.056 & 0.057 & 0.066 & 0.08 \\
\hline $\begin{array}{l}\text { Working } \\
\text { experience }\end{array}$ & -0.124 & -0.104 & -0.104 & -0.102 & -0.096 & -0.103 & -0.097 \\
\hline $\begin{array}{l}\text { Enterprise } \\
\text { scale }\end{array}$ & 0.006 & -0.012 & -0.017 & -0.012 & -0.011 & -0.024 & -0.014 \\
\hline Enterprise age & -0.109 & -0.1 & -0.099 & -0.096 & -0.101 & -0.085 & -0.072 \\
\hline Total profit & 0.095 & 0.124 & 0.126 & 0.122 & 0.123 & 0.127 & 0.1 \\
\hline Total sales & 0.019 & -0.029 & -0.028 & -0.028 & -0.025 & -0.05 & -0.049 \\
\hline $\begin{array}{c}\text { Organizational } \\
\text { change }\end{array}$ & & $0.161^{* *}$ & $0.154^{* *}$ & $0.155^{* *}$ & $0.149^{* *}$ & $0.16^{*}$ & $0.131^{*}$ \\
\hline $\begin{array}{c}\text { Employees' } \\
\text { attitudes } \\
\text { toward change }\end{array}$ & & & 0.025 & 0.03 & 0.032 & -0.005 & -0.007 \\
\hline Self-motivation & & & & -0.025 & -0.04 & & \\
\hline $\begin{array}{l}\text { Organizational } \\
\text { change } \times \\
\text { attitude of } \\
\text { employees to } \\
\text { change } \times \\
\text { self-motivation }\end{array}$ & & & & & 0.046 & & \\
\hline $\begin{array}{l}\text { Organization } \\
\text { Incentive }\end{array}$ & & & & & & 0.096 & 0.044 \\
\hline $\begin{array}{l}\text { Organizational } \\
\text { change } \times \\
\text { attitude of } \\
\text { employees to } \\
\text { change } \times \\
\text { organizational } \\
\text { incentives }\end{array}$ & & & & & & & $0.169^{*}$ \\
\hline $\mathrm{R}^{2}$ & 0.028 & 0.051 & 0.052 & 0.052 & 0.054 & 0.06 & 0.083 \\
\hline$\triangle \mathrm{R}^{2}$ & -0.002 & 0.019 & 0.016 & 0.013 & 0.12 & 0.021 & 0.042 \\
\hline $\mathrm{F}$ & 0.929 & 1.576 & 1.444 & 1.334 & 1.272 & 1.531 & $2.019^{*}$ \\
\hline
\end{tabular}

Enterprise transformation is set as the dependent variable to test the second-order adjustment effect of self-motivation and organizational incentives on enterprise transformation, and the above steps are repeated. The results are shown in Table 7 . The interaction items of organizational change, employee change attitudes and self-motivation have a significant impact on corporate transformation $(\beta=0.176, p<0.05)$, assuming H4b holds. The interaction items of organizational change, employee change attitudes and organizational incentives have a significant impact on corporate transformation $(\beta=0.239, \mathrm{p}<0.001)$, assuming H4d holds.

Table 7 Test results of second-order adjustment effect

\begin{tabular}{|c|c|c|c|c|c|c|c|}
\hline \multirow{2}{*}{ Variable } & \multicolumn{7}{|c|}{ Enterprise Transformation } \\
\cline { 2 - 8 } & $\mathrm{M} 22$ & $\mathrm{M} 23$ & $\mathrm{M} 24$ & $\mathrm{M} 25$ & $\mathrm{M} 26$ & $\mathrm{M} 27$ & M28 \\
\hline Gender & -0.045 & -0.045 & -0.045 & -0.046 & -0.047 & -0.045 & -0.039 \\
\hline Age & 0.085 & 0.057 & 0.057 & 0.075 & 0.044 & 0.056 & 0.009 \\
\hline $\begin{array}{c}\text { Education } \\
\text { background }\end{array}$ & 0.142 & 0.149 & 0.149 & 0.145 & 0.149 & 0.148 & 0.138 \\
\hline Job position & 0.072 & 0.055 & 0.055 & 0.045 & 0.05 & 0.058 & 0.078 \\
\hline $\begin{array}{c}\text { Working } \\
\text { experience }\end{array}$ & -0.122 & -0.102 & -0.102 & -0.114 & -0.09 & -0.102 & -0.093 \\
\hline Enterprise scale & -0.046 & -0.064 & -0.064 & -0.087 & -0.084 & -0.066 & -0.05 \\
\hline Enterprise age & -0.018 & -0.009 & -0.009 & -0.023 & -0.039 & -0.006 & 0.013 \\
\hline
\end{tabular}

ISSN: 0010-8189

(C) CONVERTER 2020

www.converter-magazine.info 


\begin{tabular}{|c|c|c|c|c|c|c|c|}
\hline Total profit & -0.003 & 0.025 & 0.025 & 0.043 & 0.045 & 0.026 & -0.012 \\
\hline Total sales & 0.147 & 0.1 & 0.1 & 0.102 & 0.113 & 0.095 & 0.096 \\
\hline $\begin{array}{l}\text { Organizational } \\
\text { change }\end{array}$ & & $0.158^{* *}$ & $0.158^{*}$ & $0.152^{*}$ & $0.128^{*}$ & $0.16^{*}$ & 0.119 \\
\hline $\begin{array}{c}\text { Employees' } \\
\text { attitudes toward } \\
\text { change }\end{array}$ & & & 0.0002 & -0.025 & -0.018 & -0.006 & -0.009 \\
\hline Self-motivation & & & & $0.13^{*}$ & 0.069 & & \\
\hline $\begin{array}{c}\text { Organizational } \\
\text { change } \times \\
\text { attitude of } \\
\text { employees to } \\
\text { change } \times \\
\text { self-motivation }\end{array}$ & & & & & $0.176^{*}$ & & \\
\hline $\begin{array}{c}\text { Organizational } \\
\text { incentives }\end{array}$ & & & & & & 0.022 & -0.051 \\
\hline $\begin{array}{l}\text { Organizational } \\
\text { change } \times \\
\text { attitude of } \\
\text { employees to } \\
\text { change } \times \\
\text { organizational } \\
\text { incentives }\end{array}$ & & & & & & & $0.239^{* * * *}$ \\
\hline $\mathrm{R}^{2}$ & 0.06 & 0.083 & 0.083 & 0.098 & 0.125 & 0.083 & 0.131 \\
\hline$\Delta \mathrm{R}^{2}$ & 0.03 & 0.052 & 0.048 & 0.061 & 0.085 & 0.046 & 0.092 \\
\hline $\mathrm{F}$ & $2.09^{*}$ & $2.646^{* *}$ & $2.397^{* * *}$ & $2.637^{* *}$ & $3.167^{* * * *}$ & $2.201^{* *}$ & $3.344^{* * *}$ \\
\hline
\end{tabular}

\section{Conclusion}

\subsection{Research conclusion}

On the basis of empirical research, this paper discusses the relationship between organizational change and enterprise transformation. Research indicates that:

(1) Organizational change can promote enterprise transformation. When the corporate strategy is consistent with the transformation goal, the organizational structure must be adjusted and changed accordingly, and the business process must be reorganized to serve the transformation goal efficiently. The corporate culture is coordinated with the transformation strategy and organizational structure to match the organizational transformation with the corporate transformation, and the organizational transformation will have a positive effect on the corporate transformation.

(2) When management innovation is considered as an intermediary variable, management innovation only plays a partial intermediary role in the relationship between organizational change and enterprise transformation. Research shows that in the process of enterprise transformation, organizational change and management innovation will promote enterprise transformation. Regardless of whether management innovation plays a role in improving organizational operation efficiency, or management innovation improves transformation management efficiency, it will bring benefits to the transformation of the enterprise. However, if only the organizational structure change is implemented, it will be very limited in improving the efficiency of enterprise transformation. Therefore, only by launching management innovation activities at the same time can it not only help to improve the effectiveness of organizational change, but also enable organizational change to better match the transformation of the enterprise. Therefore, high-efficiency organizational changes will benefit from high-level management innovation activities, and high-efficiency management innovation activities must make organizational changes more compatible with

ISSN: 0010-8189

(C) CONVERTER 2020

www.converter-magazine.info 
enterprise transformation. This proves that management innovation plays a part of the intermediary role in the relationship between organizational change and enterprise transformation, being an indispensable intermediary role.

(3) The attitude of employees towards change plays a moderating role in the relationship between organizational change and management innovation, as well as the relationship between organizational change and enterprise transformation. When employees adopt a positive and supportive attitude towards corporate transformation and organizational changes, or when employees see that organizational changes will bring benefits to themselves in the future, they will show a positive attitude and influence their participation in actions, and strive to adapt to the requirements of the new transformation environment. They will pursue the new expectations that the transformation may bring. This positive attitude towards change will make it easier to accept new management models and new management concepts, and promote the efficiency of transformation management.

(4) Employees' self-motivation can affect their attitudes towards change. The main performance is that when employees have good expectations for the transformation of the enterprise, their self-worth realization and the initiative to pursue achievements play a stimulating role, prompting them to take active actions to participate in the organizational change, and to realize the enterprise. The transformation is successful and unremitting efforts.

(5) Employee self-motivation does not play a second-order regulating role in the regulating effect of employee change attitudes on organizational change and management innovation. The reason is that in the process of corporate transformation, the benefits of management innovation to employees are vague or lack direct benefits. Coupled with the fetters of various interest issues in the reform, the enthusiasm of employees is frustrated, and even negative emotions are generated. The overall benefits formed by the transformation of the enterprise can enable employees to see hope for the future and show a positive attitude to support and participate in the transformation. In other words, the results of transformation are easier for employees to see clearly, and it is difficult for management innovation activities to have a sense of profit.

(6) Organizational incentives play the second-order regulatory role in the adjustment of organizational change, management innovation, and corporate transformation. The reason is that in the process of transformation, the company formulates new promotion channels, new performance appraisal and new welfare policies and other incentives to make employees trust and expect the company's transformation vision, so employees' attitudes towards change will tend to be positive. Actively participating in organizational change and management innovation activities forms a positive role in promoting enterprise transformation.

\subsection{Countermeasures and suggestions}

6.2.1 Clarify the requirements of transformation on organizational change.

First, corporations should give fully play to the leading role of transformation goals. Enterprise transformation belongs to the category of strategic management, and it is necessary to play the role of direction guidance and task guidance for transformation goals, so that organizational structure adjustment, employee thoughts and behaviors and transformation requirements are closely matched to form a high degree of consistency in the overall transformation process. Second, in the process of organizational change, we must always emphasize the importance of the direction and goals of the transformation strategy, strengthen the in-depth understanding and execution of all employees, and ensure that the organizational change supports and guarantees the transformation. Third, in accordance with the requirements of the transformation goals, corporations should reorganize the business operations of the company, optimize the process around the transformation business, clarify the positions and division of labor, reasonably allocate limited resources, and ensure the efficiency of the organization's operation. Fourth, the change of corporate culture should be actively promoted. Enterprise transformation is a major strategic change, which will inevitably involve the adjustment or even update of corporate culture, and will 
inevitably affect the thinking and behavior of employees. Therefore, proactively adjusting corporate culture is a long-term task to change and guide employees'changes in their concepts and behaviors. It requires companies to prepare in advance and resolutely implement them to play the supporting role and value enhancement role of corporate culture, and stimulate employees'enthusiasm and ownership. Corporations should enhance the cohesion of the enterprise and promote the successful transformation of the enterprise.

6.2.2 Corporations should improve and play the role of motivation.

First, it is important to mobilize employees' self-motivation initiative. By authorizing key employees, corporations should give them full trust and stimulate their sense of responsibility. Corporations should actively publicize employees' important contributions to transformation, show all employees their work results, and praise their personal values. It is important to provide promotion opportunities for capable employees, give full play to their expertise and special abilities, and stimulate their sense of accomplishment. Second, corporations should give full play to the role of organizational incentives. According to the new features of the transformation business, a more reasonable salary system and reward and punishment system have been established to mobilize the enthusiasm and initiative of employees and stimulate their management innovation capabilities. Corporations should establish a variety of flexible welfare systems to cover employees' contributions in the transformation of the company, so that every employee has a sense of transformation. It is important to establish a more fair and just promotion system, so that employees have more development opportunities through job competition and job rotation during the special period of change. In response to the new requirements of transformation on employee skills, companies should conduct targeted and timely professional and skills training so that employees can feel the importance of the company's role in the transformation and stimulate their enthusiasm to participate in the transformation.

\subsubsection{Corporations should strengthen corporate management innovation.}

It has been proved that management innovation plays a vital intermediary role in the matching of organizational change and enterprise transformation. Therefore, it is necessary to give play to the disruptive, transformative, promoting and creative role of management innovation. Through management innovation, it can coordinate and match the key transformation management areas such as organizational structure adjustment, business process reengineering, policy and system formulation, personnel use and deployment, and transformation goals. At the same time, it will play an innovative and leading role in improving management methods, creating new management models, and introducing advanced management methods and experience. Through management innovations in these areas, it is ensured that the efficiency of enterprise transformation is improved, employee behaviors are regulated, employee enthusiasm is stimulated, and the transformation goals are ultimately guaranteed.

6.2.4 Corporations should pay attention to employees' attitudes towards organizational change and transformation. First, it is crucial to pay close attention to the needs and psychological tendencies of employees, and adjust incentive policies in a timely and appropriate manner. Before the change, the company should fully understand the employees' psychological tendencies and thoughts on transformation, and adopt targeted measures to resolve employees' worries and concern about transformation. At the same time, it is necessary to understand the needs of employees in a timely manner, formulate corresponding policies to meet the needs of employees, and stimulate their enthusiasm to participate in transformation, so as to obtain employees' support for organizational change. Second, corporations should do a good job in reform propaganda. The extensive publicity of the purpose of enterprise transformation and related tasks is to actively communicate with employees, promote their understanding of the significance of transformation, and increase their enthusiasm for active participation and bear the pressure of transformation. Third, corporations should actively call on employees to participate in organizational change. The daily business activities of an enterprise cannot be separated from the participation of employees. Organizational change requires the participation of employees, which helps to promote employees' understanding of the change and increase confidence in the transformation, and transform the pressure of transformation into future development opportunities. Fourth, corporations should listen to the suggestions of 
employees extensively. Employees' positive suggestions mean that employees psychologically accept the changes and opportunities brought about by the change, which reflects their positive attitudes and behaviors to a certain extent, and helps to promote the transformation process.

\subsection{Shortcomings and Prospects}

Due to the selection of indicators in this article and the conditions set in the questionnaire, some indicators in the results are too concentrated, and the final data is subject to the subjective judgment of the respondents, so the results may have a certain deviation. In addition, due to time constraints and difficulty in the collection of questionnaires, the results may be limited by the number of samples. Whether this study has universal applicability, further verification is needed in future studies. Therefore, future research needs to choose more scientific indicators and control the scope and number of samples to make the results more accurate.

\section{Acknowledgements}

Project Source: Major Project of Soft Science in Hebei Province in 2020, Research on Matching Mechanism of Technical Resources, Capabilities and Mutational Transformation of Resource-Dependent Enterprises, Project No. 20557605 D.

\section{References}

[1] Stefanie. Faupel, Stefan. Süß, The Effect of Transformational Leadership on Employees During Organizational Change-An Empirical Analysis. Journal of Change Management, 19(3): 145-166, 2019.

[2] Y. L. Gan, X. Y. Han, X. C. Wang, Transformational leadership behavior and employees' attitudes to change: the role of change schema and uncertainty perception. Academic Research,2014(7):84-90+159-160.(Chinese)

[3] J. F. Wang, X. M. Qin, H. L. Li, A Study on the Paradigm of Enterprise Transformation Based on Competitive Advantage. Enterprise Economics,2006(4):30-33.(Chinese)

[4] J. Lin, Z. Luo, X. L. Robert, Understanding the roles of institutional pressures and organizational innovativeness in contextualized transformation toward e-business: Evidence from agricultural firms. International Journal of Information Management, 51(4):102025.1-102025.11, 2020.

[5] Espejo. R, Organizational Transformation and Learning: a Cybernetic Approach to Management University of St. Gallen, 1996(37), 568-581.

[6] Gill. A. Q, Smith. S, Beydoun. G, et al. Agile Enterprise Architecture: A Case of A Cloud Technology Enabled Government Enterprise Transformation. Ais Electronic Library, (21):456-469, 2014.

[7] Mónica. García-Rubiano, Carlos Forero-Aponte, Miguel Á. Mañas-Rodríguez, Pedro A. Díaz-Fúnez, Rubén Trigueros, José M. Aguilar-Parra. Confirmatory and Exploratory Analysis of the Questionnaire to Evaluate the Disposition towards Organizational Change (CEDCO). Sustainability, 2020, 12(16):6543.

[8] J. C. Su, H. F Lin, Review and Prospect of Management Innovation Research Perspective. Journal of Management,2010a,7(9):1343-1349+ 1357.(Chinese)

[9] Q. F. Fu, W. Xie, N. N. Zhang. The motivation, timing and process of enterprise management innovation adoption. Technical Economics, 2019,38(03):1-7.(Chinese)

[10] Constanza. Beatriz. Veloso-Besio, Alejandro . Cuadra-Peralta, Francisco Gil-Rodríguez, et al. Effectiveness of training, based on positive psychology and social skills, applied to supervisors, to face resistance to organizational change. Journal of Organizational Change Management, 2019, 32(2):251-265.

[11] Y. Fan, Y. Zhang, Z. P. Yang, An Empirical Study on the Impact of Organizational Cultural Friendliness on Employees' Attitudes to Change. Chinese Journal of Management, 2009, 6(7),910-917.(Chinese) 
[12] J. Zhao, J. F. Lu, J. F. Yu, K. Shi, The influence of management behavior strategies on employees' attitudes to change: the moderating effect of LMX. Science and Technology Progress and Policy,2012,29(04),143-147.(Chinese)

[13] Chen Jingqiu,Tong Jiajin,Wang Lei.Management Research on Staff Attitudes and Behaviors in Organizational Reform[J].China Human Resources Development,2011 (2):8-12.(Chinese)

[14] Vanessa. De. Fátima. Nery,Kettyplyn Sanches Franco, Elaine Rabelo Neiva. Attributes of the Organizational Change and Its Influence on Attitudes Toward Organizational Change and Well-Being at Work: A Longitudinal Study. The Journal of Applied Behavioral Science, 56(2):216-236, 2020.

[15] X. Q. Zeng, Y. Zhou, An empirical study on the relationship between salary incentives and innovative behaviors. Journal of Renmin University of China,2008(5),86-93.(Chinese)

[16] J. Y. Liu, An Empirical Analysis of the Relationship between Organizational Learning, Strategic Change and Organizational Performance. Investigation in Economic Issues, 2010(10):53-59.(Chinese)

[17] Bhatt. G D, A resource-based perspective of developing organizational capabilities for business transformation. Knowledge and Process Management, 2015, 7(2):119-129.

[18] G. M. Duan, W. P. Yu. Research on the Correlation between Organizational Process Reform and Organizational Performance under the Condition of ERP. Jiangsu Commercial Theory,2007(3),108-110.(Chinese).

[19] Philip. G , Mckeown. I, Business Transformation and Organizational Culture:The Role of Competency, IS and TQM[J]. European Management Journal, 2004, 22(6):624-636.

[20] Q. Q. Zhu, L. R. Long, Summary of Research on the Reaction of Foreign Employees to Change.Foreign Economics and Management,2011,33(8),41-49.(Chinese)

[21] Yu Chuanpeng, Zhang Zhengang,Lin Chunpei.Research on the Process Mechanism of Enterprise Management Innovation Based on Technology Acceptance Model[J].Scientific Research Management,2019,40(8):206-214.(Chinese)

[22] Chich-Jen Shieh. Management innovation, corporation core competence and corporate culture: the impact of relatedness. Applied Economics Letters, 2011,18(12):1121-1124.

[23] D,Amato A, Roome N . Leadership of organizational change toward an integrated model of leadership for corporate responsibility and sustainable development: A process model of corporate responsibility beyond management innovation. Corporate Governance, 2009, 9(4):421-434.

[24] Jensen, J. H., Flachs, E. M., Skakon, J., Rod, N. H., \& Bonde, J. P. Longitudinal associations between organizational change, work-unit social capital, and employee exit from the work unit among public healthcare workers: A mediation analysis. Scandinavian Journal of Work, Environment \& Health, 2019, 45(1), 53-62.

[25] Jan. Philipp. Krügel, Stefan. Traub, Reciprocity and resistance to change: An experimental study. Journal of Economic Behavior and Organization, 2018,147(3):95-114.

[26] Shin. J, Taylor. M. S, Seo. M. G, Resources for Change: the Relationships of Organizational Inducements and Psychological Resilience to Employees' Attitudes and Behaviors toward Organizational Change. Academy of Management Journal, 55(3):727-748, 2012.

[27] W. He, L. R. Long. Research on Incentive Model of Internal and External Compensation Combination.Management Review, 23(09):93-101(Chinese), 2011.

[28] S. C. Li, J. Shen, Research on Enterprise Business Transformation of Complex Product System Oriented Integrated Solution. Science of Science and Management of S. \& T, 30(8):139-146. (Chinese), 2009.

[29] Gilson. L. L, Shalley. C. E, A Little Creativity Goes a Long Way: An Examination of Teams' Engagement in Creative Processes. Journal of Management, 2004, 30(4):453-470.

[30] Frank. D. H, Obloj. T. Firm-specific human capital, organizational incentives, and agency costs: Evidence from retail banking. Strategic Management Journal, 35(9),1279-1301. 2014.

[31] Shin, J, Taylor, M. S., \& Seo, M. G, Resources for change: The relationships of organizational inducements and psychological resilience to employees' attitudes and behaviors toward organizational change. Academy of Management Journal, 55(3): 727-748, 2012. 
[32] M. Huo, Research on the relationship between enterprise IT capability, organizational change and performance in a complex dynamic environment. Tianjin University (Chinese), , 2012.

[33] Vaccaro. I. G, Jansen. J. J. P, Bosch F A J V D, et al. Management Innovation and Leadership: The Moderating Role of Organizational Size. Journal of Management Studies, 49(1),28-51, 2012.

[34] John. Humphrey, Hubert. Schmitz, How does insertion in global value chains affect upgrading in industrial clusters. Regional Studies , 36(9):1017-1027, 2002.

[35] W. J. Kong, Research on the Influencing Factors of the Transformation and Upgrading of Manufacturing Enterprises__ An Empirical Study Based on a Large Sample Questionnaire Survey of Manufacturing Enterprises in Zhejiang Province. Management World,2012(09),120-131.(Chinese)

[36] Lau. C, Woodman, R.W, Understanding Organizational Change: A Schematic Perspective. The Academy of Management Journal, 38(2):537-554, 1995

[37] W. Z. Yang, Research on the Mechanism of Technological Innovation Motivation Affecting Technological Innovation Behavior. Southwestern University of Finance and Economics, (Chinese), 2014.

[38] Y. L. Zhao, W. C. Duan, G. X. Song, Study on the Influence of Affective and Instrumental Motivation Factors on Employees' Organizational Commitment. Investigation in Economic Issues, 2009(8):107-112.(Chinese) 